\title{
3章 広色域RGBレーザバックライト液晶ディスプレイ
}

新倉栄二ं

キーワード：ディスプレイ，レーザ，広色域，液晶，Rec ITU-R BT.2020

\section{1. まえがき}

2015 年 3 月から 124/128 度 CSにて $4 \mathrm{~K}$ 放送の商用サービ スが，2015年 12 月にはケーブルテレビにて $4 \mathrm{~K}$ 専門チャネ ルの放送が開始され，家庭で高精細映像の放送が視聴でき る環境が整い始めている. また, 総務省のロードマップに よれば，2020年に開催される東京オリンピック・パラリン ピックでは, 数多くの中継が $4 \mathrm{~K} / 8 \mathrm{~K}$ で放送され, 多くの視 聴者が市販テレビで $4 \mathrm{~K} / 8 \mathrm{~K}$ 番組を楽しんでいることを想定 し，2016年にはBS17チャネルを使った $4 \mathrm{~K} / 8 \mathrm{~K}$ の試験放送 が計画されている． $4 \mathrm{~K} / 8 \mathrm{~K}$ スーパーハイビジョンの映像 フォーマットは国際電気通信連合 (ITU: International Telecommunication Union) が定める Rec.ITU-R BT.2020 (以下BT.2020) で規定されており, 特に色再現範囲につい ては，実在する表面色の色域を表す測色デー夕であるポイ ンタカラー1)を $99.9 \%$ 包含し, 現行のハイビジョン (HDTV: High Definition Television) 映像 (Rec.ITU-R BT.709以下 BT.709)の 1.7 倍 (CIE1976UCS 色度図) という非常に広い 色域としている(図1).

これまで三菱電機では, ディスプレイの広色域化開発を 行ってきた. 今回, 液晶ディスプレイのバックライト光源 に光の三原色 (RGB) すべてに半導体レーザを適用し, BT.2020が定める色域を 98.1\%カバー (CIE1976UCS色度図) する広色域な $4 \mathrm{~K}$ 液晶ディスプレイを NHK 放送技術研究所 と共同で開発し2)，2015年5月に開催されたNHK技研公開 および同年 10 月に開催されたCEATEC2015にて一般に公 開した。本報では開発した広色域RGBレーザバックライト 液晶ディスプレイについて解説する.

\section{2. ディスプレイ広色域化とレーザバックライト}

ディスプレイの広色域化には二つの方法が考えられる。 一つは光源の色純度を高める, すなわち色度図に示される 三角形の頂点をスペクトル軌跡上に近づける手法である.

\section{$\dagger$ 三菱電機株式会社 先端技術総合研究所}

"Wide Color Gamut RGB Laser Backlight LCD Display" by Eiji Niikura (Advanced Technology R\&D Center, Mitsubishi Electric Corporation, Kyoto)

$416(56)$

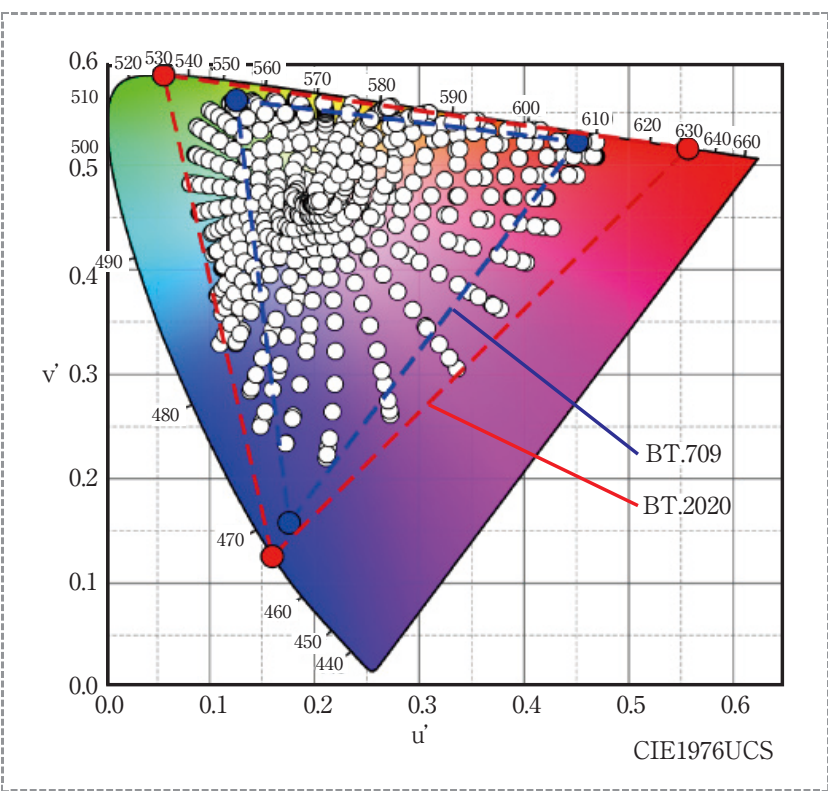

図 1 BT.2020/BT.709の色域とポインタカラー

もう一つが多原色化で, 光源に光の三原色である赤 $(R)$, 青 (B), 緑 (G) 以外の色を追加して, 色度図に示される形状を 多角形にする手法である。これまで三菱電機では, 6 原色 LED バックライト液晶モニタや 6 原色プロジェクションテ レビといった多原色ディスプレイを開発してきた. 2008年 には，更なるディスプレイの広色域化を目指し，光源に三 原色の可視光レーザダイオード (LD) を採用したリアプロ ジェクション型テレビ「LaserVue」(レーザテレビ)を製品 化した ${ }^{3)}$ ・レーザテレビの色再現範囲はBT.709に対して 175\%の広色域であり, 赤と青は半導体レーザ, 緑は赤外発 振させた基本波を波長変換して生成した。光源波長は, 赤 が $640 \mathrm{~nm}$, 緑が $532 \mathrm{~nm}$, 青が $447 \mathrm{~nm}$ である。他に類を見 ない色鮮やかな広色域テレビであったが, 後に制定された BT.2020の色域と比較するとカバー率は約 $92 \%$ に留まって いる。これは，採用した青レーザの波長が $20 \mathrm{~nm}$ 短かった ことによる.

レーザテレビ開発で培ったレーザディスプレイ技術を最 も普及している液晶テレビに適用したのが, レーザバック ライト液晶テレビである．2012年に一般ユーザに販売され 
る民生用液晶テレビとしては世界で初めて半導体レーザを バックライト光源に搭載した液晶テレビLCD-55 LSR3 (以 下，LSR3 と称する）を発売した ${ }^{4)}$. LSR3のバックライト 光源は, 赤は半導体レーザ, 緑・青は両者の混合色である シアン色LEDを採用した. 赤色は視覚特性の面でも視聴者 にアピールする色であり, 従来の液晶テレビの色再現特性 は, 白色 LEDの発光特性により他色に比べて赤色領域の色 再現性が不充分であったことから, 赤色の改善が最も効果 的と考えた。最良のコストパフォーマンスを得る観点から も, 赤のみレーザを適用し, 緑・青光源については, 新た にシアン色LEDを開発した. LSR3のバックライト光学系 は，レーザ，LEDに応じて独立した 2 枚の導光板を用いた エッジ方式を採用し, 両導光板を積層した構成としている. レーザはLEDよりも拡散性が低い特性を持つため, レーザ 光源と導光板との間にサブ導光板を配することで拡散性を 確保した。さらに，2014年にはレーザバックライトに $4 \mathrm{~K}$ 液晶パネルを搭載した 65 型の LCD-65 LS1（以下 LS1）を発 売した. LS1のバックライト構成は, 大画面化に対応する ために新たに直下方式を開発し，シアン色LEDを最適化す ることで, BT.2020の色域カバー率は約 85\%に達している.

このように, 三菱電機ではレーザバックライト技術を進 化させてきた.

\section{RGBレーザバックライト液晶ディスプレイ}

2012 年にBT.2020が制定され，ディスプレイ広色域化の 具体的な指標を得た. BT.2020の定める色域ではRGBの各 色度点がスペクトル軌跡上に存在するので, 相当する波長

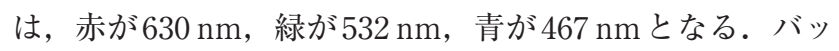
クライト光源の波長にこの波長を適用すればBT.2020の色 域を再現できるので, 現時点では単一波長で発光するレー ザが最適であると考えた。これまでのレーザバックライト では，赤の半導体レーザのみを用いてきたが，レーザバッ クライト技術をさらに進化させ, RGBとも半導体レーザを 採用することとした。

\subsection{RGBレーザバックライト}

バックライト光源にレーザを適用する場合, 先ず課題と なるのは, 発散角が小さくかつ発散角に異方性をもつレー ザ光の均一化である. LED 光の発散角は全方向に約 $120^{\circ}$ (半值全角) なのに対して, レーザ光は直交方向で発散角が 異なり，例えば，赤レーザの場合は，一方が約 $35^{\circ}$ (同), 直交方向が $7^{\circ}$ (同) と異方性を持つ (図2). 発散角の異方性 を考慮しつつ充分拡散し均一面発光するために, RGBレー ザバックライトでは透明の基材に微少量の拡散材を含有さ せた丸棒状の導光体 (導光棒) を用いた. 図3に導光棒の発 光原理を示す.レーザ光源から出射された光は導光棒の端 面から入射し, 導光棒内を全反射しながら伝播する. 伝播 光が, 導光棒内の拡散材に当たると散乱し, 光の進行方向 が変化するので, 全反射条件を満たさなかった光が導光棒

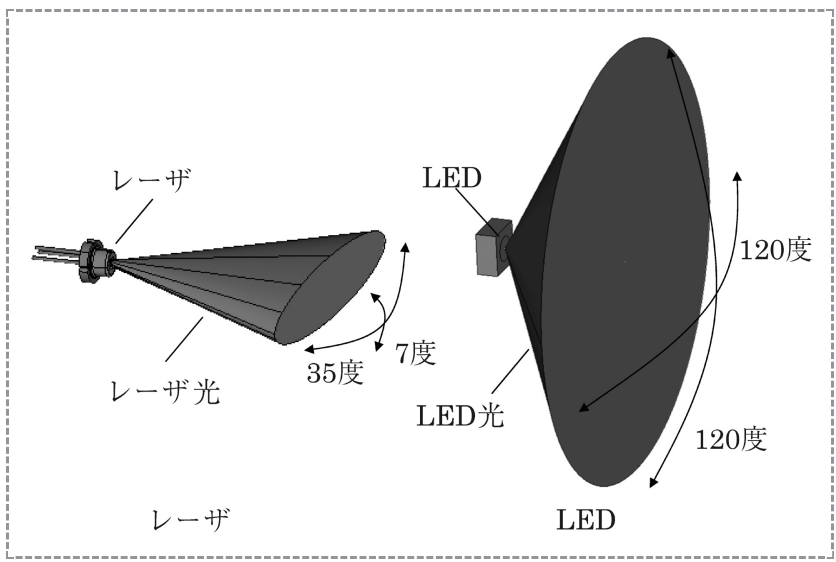

図2 光源発散角の違い (イメージ図)

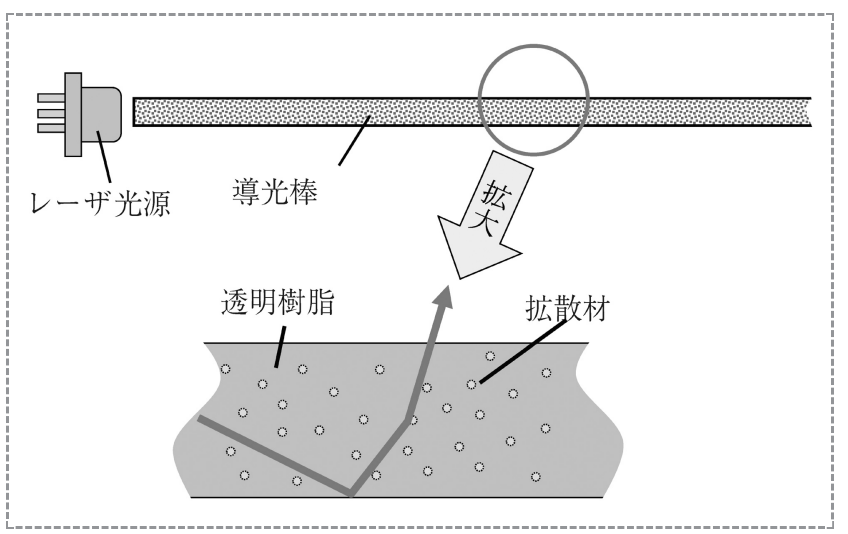

図3 導光棒の発光原理

外に出射される. 出射光は導光棒の周方向に均一に広がり, 蛍光管のように発光する. 丸棒内での伝播光は, 全反射す る反射角が 3 次元的に変化すること, 拡散材の散乱によっ て光を出射すること, によって発散角異方性の影響を無視 できるレベルまで抑制している，LED等従来の光源にこの ような導光棒を用いると, 特に入射端面近傍で全反射条件 を満たさない光が漏れ出し, 大きな入光ロスが発生してし まう.すなわち, 導光棒はレーザの発光特性に適した導光 体と言える. また, 導光棒から出射された光は導光棒の長 手方向に光強度分布を持つが，導光棒内の拡散材含有濃度 を調整することで，画面中央部が最も明るくなるよう最適 化した。

バックライトにRGB三色レーザを用いるうえでのもう一 つの課題は, 色むらの抑制である. 各色レーザ光源の光出 力に応じて光源数を決めると色ごとに必要数量が異なるこ とになる，その場合，1個の光源が照明する領域 (面積) が 色によって異なるので, 色むらが生じ易い。 そのため, RGB レーザバックライトでは, 赤・緑・青各色の光源数を 同数とした. 導光棒の発光特性は光源波長による差異が小 さいので, 画面の上側から順番に赤, 緑, 青の順で発光す るよう光源を配置した。図4に示すように，光源は導光棒 


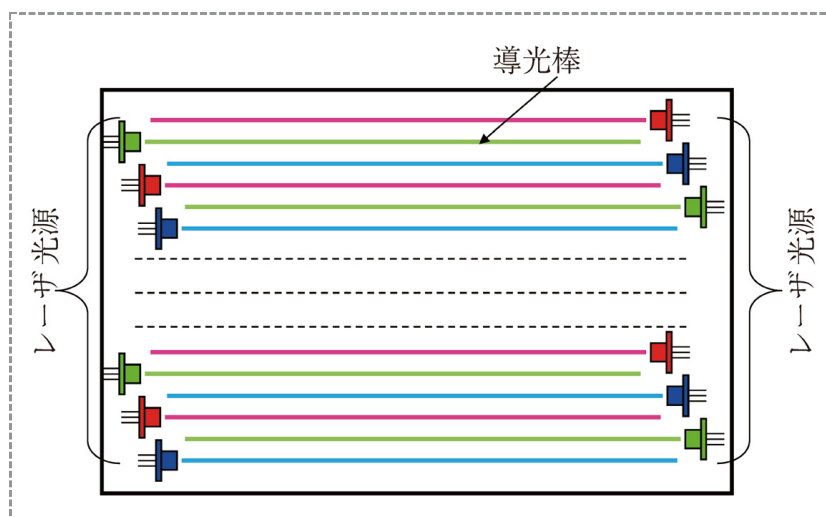

図4 導光棒および光源の配置

の片端に配置するので，画面の右側は赤，青，緑の順に， 左側は緑，赤，青の順に並ぶことになる．導光棒はパネル 面から所定の投射距離を確保してバックライトの底面側に 配置し，空間で赤，緑，青を混色させる構成とした。また， 光源は，画面全体を水平方向に複数分割して分割領域ごと に各色レーザの光出力を制御することで，画面全体の色む らを抑制している.

RGB レーザバックライトでは, レーザ光源は画面の左右 両端部に配置するエッジ方式であるが，発光する導光棒は 直下方式のようにバックライト底面に配置するので, エッ ジ/直下の両方式をミックスした独自のバックライト構成 となっている.

\section{2 光 源}

BT.2020が定める色域は色度図に示されるスペクトル軌 跡上のRGBを三原色として規定されており, 各色の波長は それぞれ $630 \mathrm{~nm}, 532 \mathrm{~nm}, 467 \mathrm{~nm}$ に相当している. RGB レーザバックライトでは，この波長をターゲットとして レーザを選定した（ただし，赤レーザは $638 \mathrm{~nm}$ )。また， 信頼性と取扱い易さの観点からもレーザ素子を金属製の容 器 (パッケージ) に封入したCANパッケージタイプを採用 し, 各色とも外形寸法が同じものとした。 なお，パッケー ジのフランジ (ステム) 部の直径は $\phi 9.0 \mathrm{~mm}$ である.

\section{3 カラーフィルタ}

液晶ディスプレイとしてBT.2020の広色域特性を活かす ためには, 光源の色純度を高めることによるバックライト 光の広色域化が必要であることはすでに述べたが, 液晶パ ネル内部のカラーフィルタの最適化も必要となる. 図5に カラーフィルタの透過特性と光源波長を模式的に示す. 図 中曲線で示すのがカラーフィルタの透過特性で, 赤, 緑, 青, 各色ともすそ野部分で透過帯域が重なりあっている. カラーフィルタの透過帯域と光源波長を比較すると, 特に 緑の光源光が青のカラーフィルタの透過帯域に重なってい る.このような透過特性では, 緑の光源光が青のカラー フィルタに混ざり込み色純度を下げる. 混ざり込みを改善 するため, 図中点線で示すように，青のカラーフィル夕を

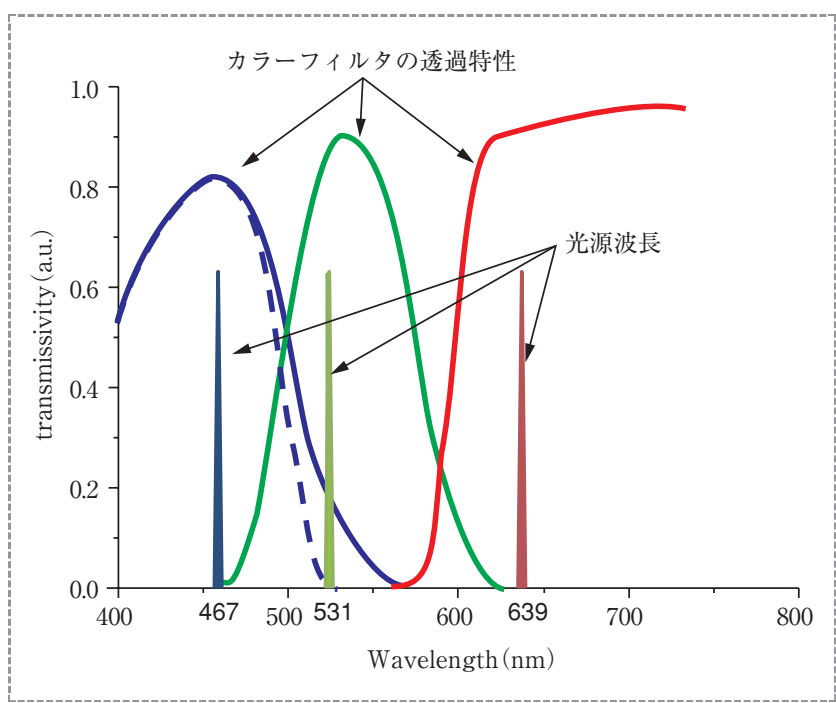

図５光源スペクトルとカラーフィルタの透過特性

調整し透過帯域幅を狭めた。この改善により, 色の混ざり 达みを回避しパネルによる色純度の低下を抑制した。

\section{4. ディスプレイの光学性能}

本ディスプレイの色域を測定した結果を図6の色度図 (CIE1976UCS) に示す. BT.2020の色域をほぼガーーしてお り，色域のカバー率は $98 \%$ であった。また液晶パネル越しに 測定した光源波長はそれぞれ $639 \mathrm{~nm}, 530 \mathrm{~nm}, 465 \mathrm{~nm}$ で あった。レーザ光源単体の波長はBT.2020が定める色域の 相当波長に合わせて選定しているので, 液晶パネルを透過 することで, 特に緑と青の波長が $2 \mathrm{~nm}$ 程度短波長側にシ フトしていたことになる.これは, カラーフィルタの透過 特性の調整が充分ではなく, 青のカラーフィルタに緑の レーザ光が混ざり込んだだけではなく, 緑のカラーフィル 夕に青のレーザ光も混ざり达んでいたことを示している. カラーフィルタの透過特性をさらに狭带域化できれば, BT.2020の色域カバー率を限りなく 100\%に近づけることが 可能と考える.

\section{5. むすび}

三菱電機と NHK放送技術研究所は共同で, RGB半導体 レーザをバックライト光源に採用することで，BT.2020が 定める色域にほぼ対応した超広色域な色再現性を実現した RGBレーザバックライト液晶ディスプレイを開発した。こ のディスプレイは，2015年5月に開催された NHK技研公 開と, 同年 10 月に開催されたCEATEC JAPAN 2015に出 展, 一般公開した。

今回開発したディスプレイは $4 \mathrm{~K}$ 液晶パネルを搭載した 構成であったが, 現在開発が進んでいる $8 \mathrm{~K}$ 液晶パネルを 搭載することも可能である. 今後の RGB レーザバックライ トの更なる進化が期待できる.

(2016年 2 月 5 日受付) 


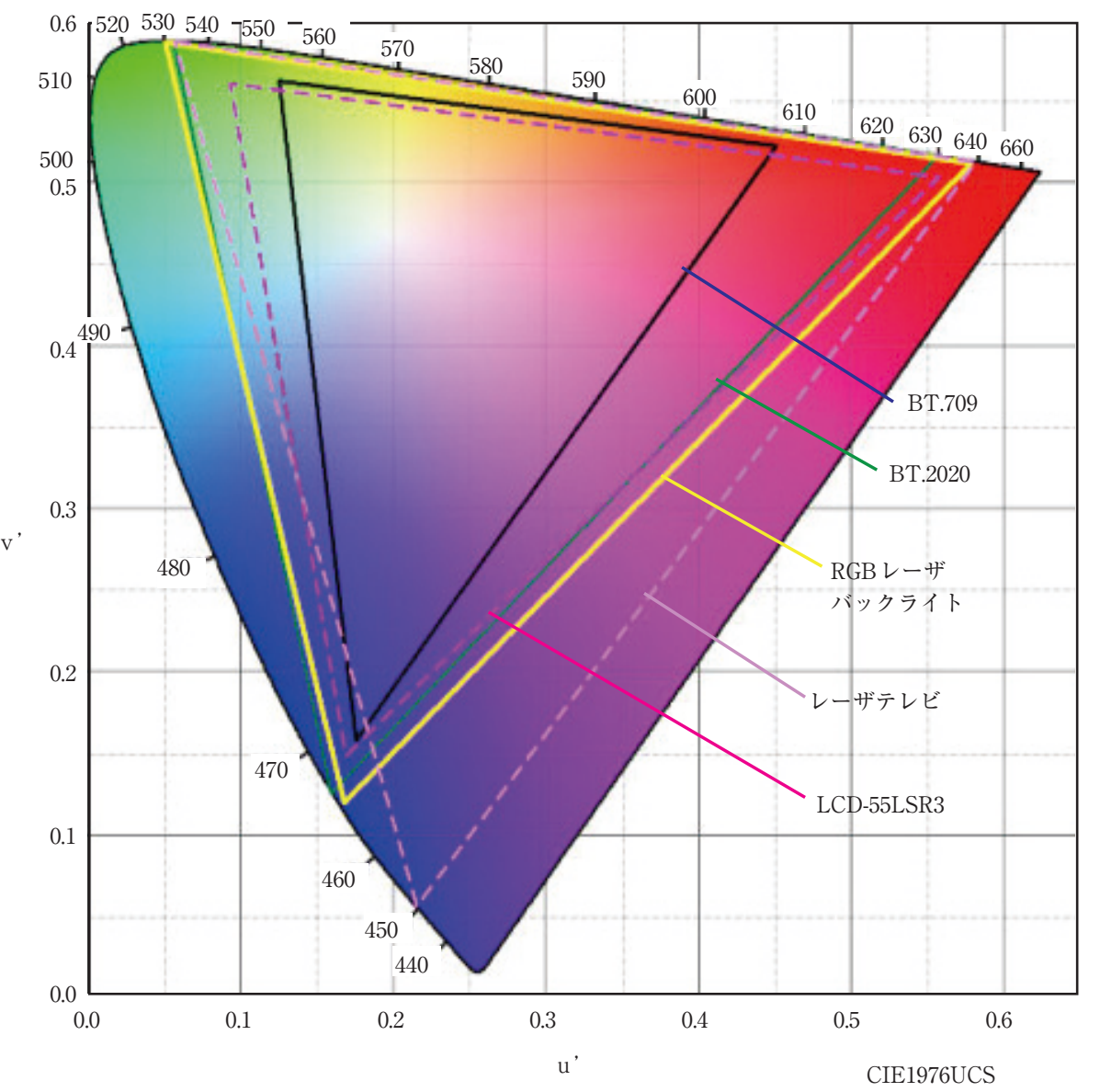

図6 開発品の色再現範囲

\section{〔文 献〕}

1) M.R.Pointer: "The gamut of real surface colors", Color Researchand Applicaion, 5, 3, pp.144-155 (1980)

2) E.Niikura, et al.: "Development of RGB Laser Backlit Liquid Crystal Display", IDW'15, pp1096-1099 (2015)

3) H. Sugiura, et al.: "65-inch, Super Slim, Laser TV with Newly Developed Laser Light Sources", SID08 Digest, pp.854-857 (2008)

4) E. Niikura et al.: "Dvelopment of Laser Backlighting LCD Television", IDW'12, pp287-288 (2012)

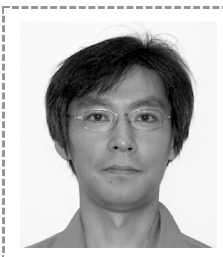

新倉 采二 1992年, 信州大学工学部精密工学科 卒業. 同年，三菱電機 (株) 入社. 現在，同社先端技 術総合研究所所属. 映像表示機器のメカニズム開発, レーザディスプレイ開発に従事. 2012年，技術振興賞 進歩開発賞受賞. 